\title{
Impact of Nutrient Management Technologies, Soil Biomass and Enzymatic Activities in Transplanted Rice (Oryza sativa L.) Under Irrigated Domains of Eastern Plain Zone in India
}

\author{
Ajay Babu ${ }^{1 *}$, Sudhanshu Verma ${ }^{2}$, Sant Sharan Singh $\operatorname{Yadav}^{1}$ and Yad Vir Singh ${ }^{1}$ \\ ${ }^{1}$ Department of Soil Science and Agricultural Chemistry, Banaras Hindu University, \\ Varanasi-221 005 (U.P.) India \\ ${ }^{2}$ Department of agronomy, Banaras Hindu University Varanasi-221 005 (U.P.) India \\ *Corresponding author
}

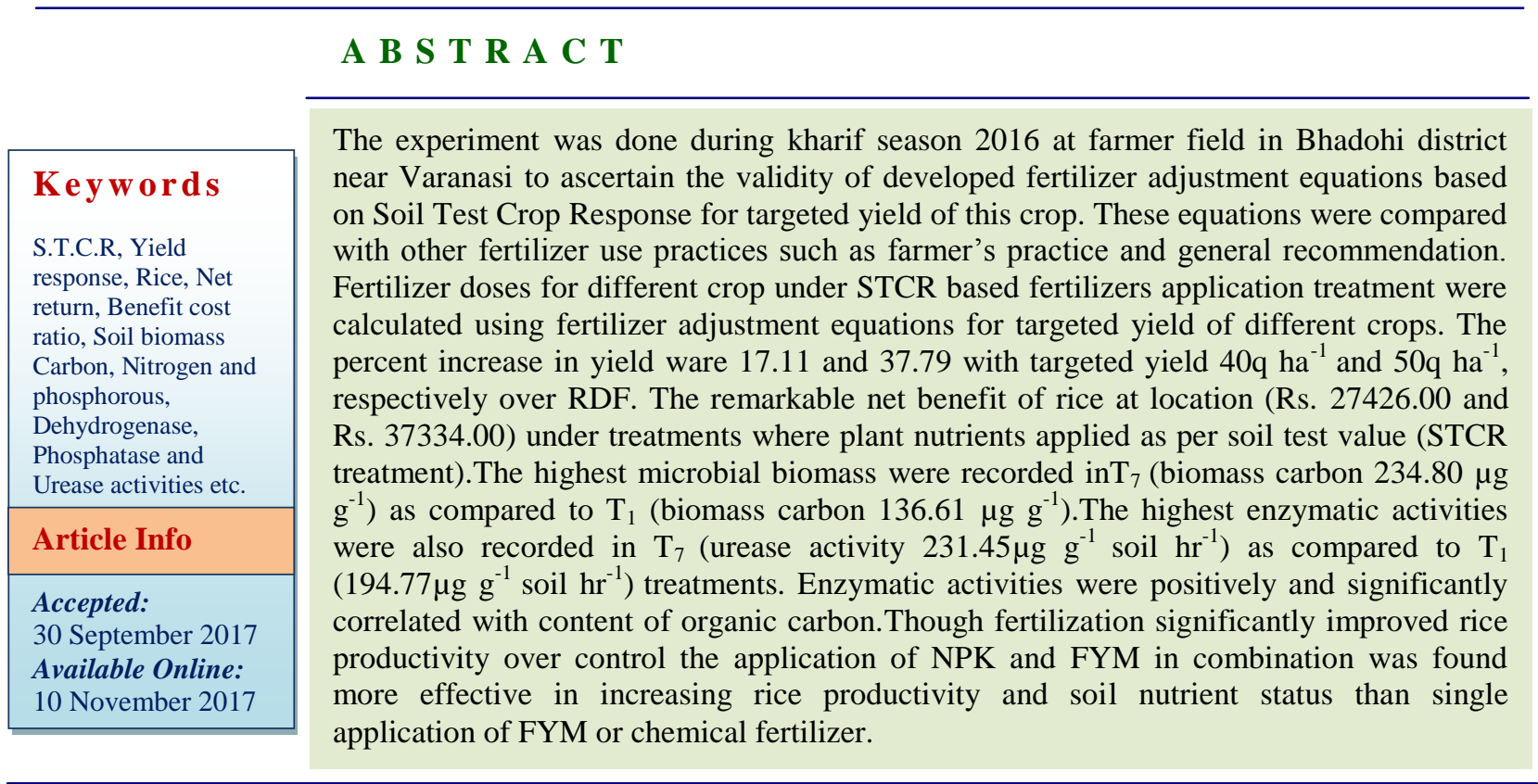

\section{Introduction}

Rice is an important staple food that provides $60-70 \%$ of body calorie intake of the consumers (Barah and Pandey, 2005). To assess food security in rice consuming country of the world, rice production should be increased by $50 \%$ in this country by 2025 . This additional rice will have to be produced on less land with less water, less labour and chemical. Similarly, to achieve the projected targets of 680 and 771 million tons by 2015 and 2030, respectively, the productivity of rice has to be increased through the addition of suitable integrated approaches. Rice based cropping systems are the major production system contributing to food production. Current crop production systems are characterized by inadequate and imbalanced uses of fertilizer e.g. blanket fertilizer recommendation over large domains with least regard to the variability in soil fertility 
and productivity. Nutrients available in soil are rarely present in adequate amount and in balanced proportion to meet the nutrient requirement of the crops. Soil test provides the actual information about the amounts of nutrients available in the soil and their imbalance, while fertilizer recommendation aims at correcting the imbalances of nutrients according to crop requirement. Several approaches have been used for fertilizer recommendation based on soil test so as to attain maximum yield per unit of fertilizer use.

Among the various approaches, the targeted yield approach has been found popular in India. The theory of formulating optimum fertilizer recommendation for targeted yield was first given by Truog (1960), which was further modified by Ramamoorthy et al., (1967).Fertilizer adjustment equation developed to different crops for agro climate zones are verified for usefulness at farmer fields by conducting multi location validation trials.

The microbial population plays a vital role in ecosystem because approximately $90 \%$ of the soil processes are related with microorganisms. Soil microbial population are the driving force behind regulating soil processes such as organic matter decomposition and nutrient cycling, it is imperative to have a better understanding of the factors that regulate its size, activity, and structure (Masto et al., 2006). Soils containing a high microbial diversity are characteristic of a healthy soil-plant relationship, whereas those with low microbial diversity are characterized as an unhealthy soil that often hardly responds to environmental changes (Tejada et al., 2011).

The enzymatic activities of soil can be used as an indicator of soil microbial diversity in increasing biochemical reactions which are important for the life of soil micro-organisms, organic wastes decomposition, organic matter formation and nutrients cycling (Tabatabai, 1994). The microbial population dynamics is governed by interactions between plant type, climate, and management practices. The soil microbial biomass in soil system responds more effective to management practices than organic matter and is often used as an indicator of soil quality (Ge et al., 2010). Soil microbial biomass is an important ecological indicator and acts as a source and sink of available nutrient for plant growth. It is supposed to be an integral part of decomposer subsystem. Soil microorganisms play a crucial role in ecosystem functions such as organic matter decomposition, nutrient cycling, transformation, mineralization etc. It also provides information regarding the organic matter decomposition, nutrient cycling, soil fertility restoration and development of ecosystem function in tropical abandoned agro ecosystems. A small change in soil microbial biomass affects directly on ecosystem stability and soil quality.

Therefore microbiological status is considered as a suitable indicator of soil health during restoration process of degraded agroecosystems. The microbial biomass is a living component of soil organic matter, constituting $1-5 \%$ of total organic matter content and it responds more quickly to the changes in soil conditions than Soil organic matter.

To increase the crop productivity, use of highyielding varieties with optimum levels of inputs is very much needed, but the decision on fertilizer use would require an in-depth knowledge of the expected crop yield response to nutrient application, which is a function of crop nutrient needs, supply of nutrients from indigenous sources, and the short- and long-term fate of the fertilizer doses applied to a soil (Dobermann et al., 2003). 


\section{Materials and Methods}

The experiment was conducted during kharif season of 2016 in farmer field at location Raimalpur-Village, Bhadohi District near Varanasi.

The trial was laid out in Randomized Complete Block Design (RCBD) with seven treatments and three replication at farmer's field $\left(520 \mathrm{~m}^{2}\right)$ location during the study period. The treatments are as follows:

$\mathrm{T}_{1}$ : Control - NPK @ 0:0:0 kg ha ${ }^{-1}$

$\mathrm{T}_{2}$ : Farmer's practice - NPK @ 100:40:40 kg $\mathrm{ha}^{-1}$

$\mathrm{T}_{3}$ : General recommended dose (GRD) @ 120:60:60 NPK kg ha ${ }^{-1}$

$\mathrm{T}_{4}$ : NPK application based on soil test crop response (NPK@ 99:48:59 $\mathrm{kg} \mathrm{ha}^{-1}$ )

$\mathrm{T}_{5}$ : NPK application based on soil test crop response (NPK@ 145:62:88 $\mathrm{kg} \mathrm{ha}^{-1}$ )

$\mathrm{T}_{6}$ : NPK application based on soil test crop response (NPK-95-47-58 $\mathrm{kg} \mathrm{ha}^{-1} \& 2 \mathrm{t} \mathrm{FYM)}$

$\mathrm{T}_{7}$ : NPK application based on soil test crop response (NPK-140-60-85 $\mathrm{kg} \mathrm{ha}^{-1} \& 2 \mathrm{t}$ FYM)

The equation used for calculating NPK recommended dose for target yield developed by Regar and Singh, 2014 for Alluvial soils of Varanasi region, was used on the basis of soil test value. Based on this value, the fertilizer doses for different treatments were calculated for fertilizer recommendation. Soil test based recommendation for yield target by utilizing the fertilizer adjustment equation.

Nitrogen dose $\left(\mathrm{kg} \mathrm{ha}^{-1}\right)=4.76 \mathrm{~T}-0.49 \mathrm{SN}-$ $0.34 F Y M-N$
Where,

$\mathrm{T}=$ Yield target $\left(\mathrm{q} \mathrm{ha}^{-1}\right) \mathrm{SN}+$ Alkaline $\mathrm{KMnO}_{4}-\mathrm{N}$

$\mathrm{SN}=$ Initial test value - nitrogen

FYM = Farm Yard Manure

Phosphorus dose $\left(\mathrm{kg} \mathrm{ha}^{-1}\right)=1.53 \mathrm{~T}-1.41 \mathrm{SP}-$ 0.09FYM-P

Where,

$\mathrm{T}=$ Yield target $\left(\mathrm{q} \mathrm{ha}^{-1}\right) \mathrm{SP}+$ Olsen's P $(\mathrm{kg}$ $\mathrm{ha}^{-1}$ )

Olsen's P = Initial soil test value- Phosphorus

FYM = Farm Yard Manure

Potassium dose $\left(\mathrm{kg} \mathrm{ha}^{-1}\right)=2.92 \mathrm{~T}-0.35 \mathrm{~K}-$ 0.11FYM-K

Where,

$\mathrm{T}=$ Yield target $\left(\mathrm{q} \mathrm{ha}^{-1}\right) \mathrm{SK}+$ Amm. Ac.- $\mathrm{K}$ $\left(\mathrm{kg} \mathrm{ha}^{-1}\right)$

Amo. Ac.-K = Initial soil test valuePotassium

Using with the above equations, the quantity of fertilizer nutrients required for achieving $40 \mathrm{q} \mathrm{ha}^{-1}$ and $50 \mathrm{q} \mathrm{ha}^{-1}$ grain yield of rice was worked out.

Data on plant height $(\mathrm{cm})$, number of tillers hill $^{-1}$, panicles plant ${ }^{-1}$, grain and straw yield (tonne $\mathrm{ha}^{-1}$ ) was recorded at maturity during the experimentation. Data was analysed statistically according to Fisher's analysis of variance technique (Steel et al., 1997) and critical difference (CD) at 5\% probability level was applied to compare the treatment's means. 


\section{Experimental soil}

Initial soil samples were collected from each location and analyzed for $\mathrm{pH}$ was determined in 1:2.5 soil-water suspension by potentiometer method (Jackson1973). Electrical conductivity was determined extract using Conductivity Bridge and expressed as dSm-1 (Jackson 1973), organic carbon (Walkely and Black, 1934), alkaline $\mathrm{KMnO}_{4}-\mathrm{N}$ (Subbiah and Asija, 1956), Olsen$\mathrm{P}$ (Olsen et al., 1954), $\mathrm{NH}_{4} \mathrm{OAc}-\mathrm{K}$ (Hanway and Heidal, 1952), Soil biomass C, N, P Fumigation method(Edwards and Bremner 1967), Urease activity Colorimeter method (Bremner and Douglas, 1971), Alkaline Phosphatase activity Colorimeter method (Tabatabai, and Bremner (1969) and Dehydrogenase activity Colorimeter method (Casida et al., 1964). The initial soil fertility status for location is shown in Table 1. The crop variety HUR 105 was used with the seed rate of $15 \mathrm{~kg} \mathrm{ha}^{-1}$ as the said variety is recurrently used for paddy cultivation by most of the farmers of the area. The soil was puddled at desirable field condition followed by planking. Nitrogen $(\mathrm{N})$, Phosphorus $(\mathrm{P})$ and Potassium (K) were applied in the form of urea, diammonium phosphatase (DAP) and muriate of potash (MOP) respectively. Whole $\mathrm{P}, \mathrm{K}$ and one third of the $\mathrm{N}$ were side dressed at the time of transplanting, while the remaining $\mathrm{N}$ was top dressed in two splits at tillers initiation and pre-flowering stages respectively. The crop was harvested manually during $2^{\text {nd }}$ week of November, 2016. After harvest of rice, soil samples were taken from the surface layer (0-15) of seven treatments and three replications. Physicochemical properties of the initial soil samples were recorded in the following Table 1.

\section{Results and Discussion}

The data pertaining to the grain yield of rice under different treatments at farmer field has been presented in Table 2. The treatment $\mathrm{T}_{7}$ receiving 140-60-85 and 2, NPK kg ha ${ }^{-1}$ and FYM t ha ${ }^{-1}$ yield was significantly higher. The highest $\left(51.30 \mathrm{q} \mathrm{ha}^{-1}\right)$ yield of rice was obtained with treatment $T_{7}$ followed by $T_{6}$, $\mathrm{T}_{5}, \mathrm{~T}_{4}, \mathrm{~T}_{3}$ and $\mathrm{T}_{2} ; 43.60,46.50,38.40,37.23$, $31.40, \mathrm{q} \mathrm{ha}^{-1}$, respectively and lowest $(22.05 \mathrm{q}$ $\mathrm{ha}^{-1}$ ) was found in the treatment $\mathrm{T}_{1}$. The combine use of fertilizer and organic manure on the basis of soil test value produce significantly higher yield as compared to blanket application. The Combined application of organic manure and chemical fertilizers would be quite promising not only in providing greater stability in production, but also in maintaining better soil fertility. Thus, the balanced use of fertilizer either alone or in combination with FYM is necessary for sustaining soil fertility and productivity of crop. Similarly Shah and Kumar (2014) also reported that integrated nutrient management showed significant influence on productivity of rice. The experimental field of Shri Anand Mohan Maurya, the actual yield obtained was around $\pm 5 \%$ from targeted yield. The farmer Shri Anand Mohan Maurya, $51.30 \mathrm{q} \mathrm{ha}^{-1}$ yield obtained from targeted yield of $50 \mathrm{q} \mathrm{ha}^{-1}$ with higher benefit: cost ratio (3.94) as compare to farmer's practice (1.90) and General Recommendation Dose (2.39). The fertilizer recommendation for farmer practices is 100 $\mathrm{N}$ : $40 \mathrm{P}: 40 \mathrm{~K}, \mathrm{~kg} \mathrm{ha}^{-1}$ and for $50 \mathrm{q} \mathrm{ha}^{-1}$ target yield treatment recommended on the basis of soil test value is $140 \mathrm{~N}$ : $60 \mathrm{P}: 85 \mathrm{~K} \mathrm{~kg} \mathrm{ha}^{-1}+2$ ton FYM. In this way treatment of targeted yield $50 \mathrm{q} \mathrm{ha}^{-1}$ was found most economic treatment as compare to farmer practices and general recommendation. Similar results were also reported by Singh et al., (2015).

\section{Effect of different treatments on nutrient uptake by rice}

Effects of different treatments on nutrient uptake by rice were recorded in Table 4 . 
Table.1 Physico-chemical properties of the initial soil samples

\begin{tabular}{|c|l|c|}
\hline S.No. & \multicolumn{1}{|c|}{ Characteristics } \\
\hline \multirow{2}{*}{1.} & Texture & 52.30 \\
\cline { 2 - 3 } & Sand $(\%)$ & 30.60 \\
\cline { 2 - 3 } & Silt $(\%)$ & 17.10 \\
\cline { 2 - 3 } & Clay $(\%)$ & Sandy loam \\
\hline & Textural class & 8.0 \\
\hline 2. & $\mathrm{pH}(1: 2.5)$ Soil water suspension & 0.26 \\
\hline 3. & EC $(1: 2.5)$ Soil water suspension $\left(\mathrm{dSm}^{-1}\right)$ & 0.45 \\
\hline 4. & Organic carbon $(\%)$ & 183 \\
\hline 5. & Available Nitrogen $\left(\mathrm{kg} \mathrm{h}^{-1}\right)$ & 12 \\
\hline 6. & Available Phosphorus $\left(\mathrm{kg} \mathrm{ha}^{-1}\right)$ & 163 \\
\hline 7. & Available Potassium $\left(\mathrm{kg} \mathrm{h}^{-1}\right)$ & 134 \\
\hline 8. & Soil biomass Carbon $\left(\mu \mathrm{g} \mathrm{g}^{-1}\right)$ & 25 \\
\hline 9. & Soil biomass Nitrogen $\left(\mu \mathrm{g} \mathrm{g}^{-1}\right)$ & 9 \\
\hline 10. & Soil biomass Phosphorous $\left(\mu \mathrm{gg}^{-1}\right)$ & 189 \\
\hline 11. & Urease Activity $\left(\mu \mathrm{g} \mathrm{g} \mathrm{g}^{-1} \mathrm{soil} \mathrm{h}^{-1}\right)$ & 132 \\
\hline 12. & Dehydrogenase activity $\left(\mu \mathrm{g} \mathrm{TPF}^{-1}\right.$ soil $\left.^{-1}\right)$ & 40 \\
\hline 13. & Alkaline phosphatase activity $\left(\mu \mathrm{g} \mathrm{p}-\right.$ nitrophenol $^{-1}$ soil h$\left.^{-1}\right)$ & \\
\hline
\end{tabular}

Table.2 Effect of different treatments on grain and straw yield of rice

\begin{tabular}{|c|c|c|}
\hline Treatments & Grain yield $\left(\mathbf{q ~ h a}^{-1}\right)$ & Straw yield $\left(\mathbf{q} \mathbf{~ h a}^{-1}\right)$ \\
\hline Shri Anand Mohan Maurya & \multicolumn{2}{|c|}{} \\
\hline $\mathrm{T}_{1}$ & 22.05 & 33.91 \\
\hline $\mathrm{T}_{2}$ & 31.40 & 45.46 \\
\hline $\mathrm{T}_{3}$ & 37.23 & 52.17 \\
\hline $\mathrm{T}_{4}$ & 38.40 & 59.44 \\
\hline $\mathrm{T}_{5}$ & 46.50 & 71.36 \\
\hline $\mathrm{T}_{6}$ & 43.60 & 63.89 \\
\hline $\mathrm{T}_{7}$ & 51.30 & 72.28 \\
\hline CD at 5 \% & $\mathbf{2 . 3 2}$ & $\mathbf{3 . 5 7}$ \\
\hline
\end{tabular}

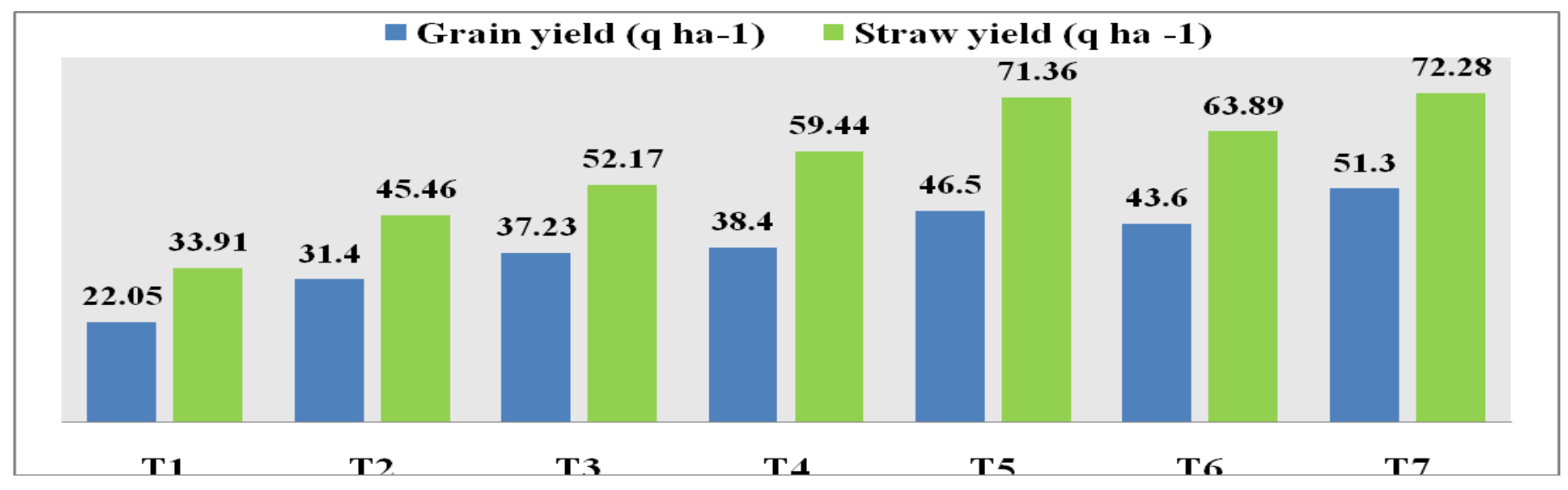


Table.3 Effect of different treatments on net benefit and economics of rice crop

\begin{tabular}{|c|c|c|c|c|c|c|c|c|}
\hline $\begin{array}{c}\text { Fertilizer dose } \\
\text { NPK }\left(\mathrm{kg} \mathrm{ha}^{-1}\right) \& \\
\text { FYM }\left(\mathrm{t} \mathrm{ha}^{-1}\right)\end{array}$ & $\begin{array}{c}\text { Actual } \\
\text { mean } \\
\text { yield } \\
\left(\text { kg ha }^{1}\right) \\
\end{array}$ & $\begin{array}{c}\text { Addition } \\
\text { al yield } \\
\left(\mathbf{k g ~ h a}^{1}\right)\end{array}$ & $\begin{array}{c}\text { Value of } \\
\text { additiona } \\
\text { l yield } \\
\text { (Rs.) }\end{array}$ & $\begin{array}{l}\text { Cost of } \\
\text { fertilizer } \\
\quad \text { (Rs.) }\end{array}$ & $\begin{array}{c}\text { Net } \\
\text { benefi } \\
t \text { (Rs.) }\end{array}$ & $\begin{array}{c}\mathrm{B} / \mathrm{C} \\
\text { ratio }\end{array}$ & $\begin{array}{c}\text { Deviatio } \\
\mathrm{n} \text { in yield } \\
(\%)\end{array}$ & $\begin{array}{c}\text { Increase } \\
\% \text { yield } \\
\text { Over RDF } \\
(\%) \\
\end{array}$ \\
\hline $\mathrm{T}_{1}(0-0-0)$ & 2205 & - & - & - & - & - & & \\
\hline $\mathrm{T}_{2}(100-40-40)$ & 3140 & 935 & 14960 & 5154 & 9806 & 1.90 & & \\
\hline $\mathrm{T}_{3}(120-60-60)$ & 3723 & 1518 & 24288 & 7164 & 17124 & 2.39 & & \\
\hline $\mathrm{T}_{4}(99-48-59)$ & 3840 & 1635 & 26160 & 5580 & 20580 & 3.69 & -4.00 & 3.14 \\
\hline $\mathrm{T}_{5}(145-62-88)$ & 4650 & 2445 & 39120 & 8089 & 31031 & 3.84 & -7.00 & 24.90 \\
\hline $\mathrm{T}_{6}(95-47-58 \& 2)$ & 4360 & 2155 & 34480 & 7054 & 27426 & 3.89 & 9.00 & 17.11 \\
\hline $\mathrm{T}_{7}(140-60-85 \& 2)$ & 5130 & 2925 & 46800 & 9466 & 37334 & 3.94 & 2.60 & 37.79 \\
\hline
\end{tabular}

Paddy@Rs.16.00/kg, N@Rs. 15.39/kg, $\mathrm{P}_{2} \mathrm{O}_{5} @$ Rs 56.25/kg, $\mathrm{K}_{2} \mathrm{O} @$ Rs 26.66/kg, FYM @Rs 0.75/kg

Table.4 Effect of different treatments on nutrient uptake by rice

\begin{tabular}{|c|c|c|c|c|c|c|c|c|c|}
\hline \multicolumn{10}{|c|}{ Shri Anand Mohan Maurya } \\
\hline \multirow[t]{2}{*}{ Treatments } & \multicolumn{3}{|c|}{ Grain uptake (kg ha $\left.{ }^{-1}\right)$} & \multicolumn{3}{|c|}{ Straw uptake $\left(\mathrm{kg} \mathrm{ha}^{-1)}\right.$} & \multicolumn{3}{|c|}{ Total uptake (kg ha ${ }^{-1)}$} \\
\hline & $\mathbf{N}$ & $\mathbf{P}$ & $\mathbf{K}$ & $\mathbf{N}$ & $\mathbf{P}$ & $\mathbf{K}$ & $\mathbf{N}$ & $\mathbf{P}$ & $\mathbf{K}$ \\
\hline $\mathrm{T}_{1}$ & 27.56 & 4.63 & 5.29 & 10.29 & 0.72 & 45.53 & 37.76 & 5.34 & 50.82 \\
\hline $\mathrm{T}_{2}$ & 46.79 & 6.91 & 7.85 & 15.00 & 1.50 & 65.46 & 61.79 & 8.41 & 73.31 \\
\hline $\mathrm{T}_{3}$ & 59.20 & 9.68 & 10.05 & 18.78 & 1.93 & 81.39 & 77.98 & 11.61 & 91.44 \\
\hline $\mathrm{T}_{4}$ & 64.51 & 10.37 & 11.90 & 22.59 & 2.44 & 94.52 & 87.10 & 12.81 & 106.42 \\
\hline $\mathrm{T}_{5}$ & 79.52 & 14.88 & 17.21 & 29.31 & 3.50 & 124.18 & 109.49 & 18.38 & 141.38 \\
\hline $\mathrm{T}_{6}$ & 75.43 & 13.52 & 14.39 & 25.20 & 3.00 & 103.51 & 101.63 & 16.53 & 117.90 \\
\hline $\mathrm{T}_{7}$ & 90.29 & 17.96 & 20.55 & 31.80 & 3.69 & 128.67 & 122.09 & 21.64 & 150.22 \\
\hline C D at $5 \%$ & $\mathbf{0 . 8 3}$ & 0.42 & 0.39 & 0.698 & 0.061 & 1.232 & 1.56 & 1.41 & 1.11 \\
\hline
\end{tabular}

Table.5 Effect of different treatments on soil fertility of post-harvest soil

\begin{tabular}{|c|c|c|c|c|c|c|}
\hline Treatments & $\mathbf{p H}$ & $\mathbf{E C}\left(\mathbf{d S m}^{-1}\right)$ & $\mathbf{O C}(\%)$ & $\mathbf{N}$ & $\mathbf{3}$ & $\mathbf{3}$ \\
\cline { 4 - 6 } & & & & \multicolumn{3}{|c|}{$\mathbf{( k g ~ h a}^{\mathbf{- 1})}$} \\
\hline $\mathrm{T}_{1}$ & 8.29 & 0.13 & 0.39 & 185.66 & 14.11 & 165.51 \\
\hline $\mathrm{T}_{2}$ & 8.25 & 0.16 & 0.43 & 188.25 & 16.88 & 168.26 \\
\hline $\mathrm{T}_{3}$ & 8.31 & 0.32 & 0.47 & 194.22 & 17.96 & 173.47 \\
\hline $\mathrm{T}_{4}$ & 8.38 & 0.22 & 0.51 & 200.17 & 21.22 & 179.12 \\
\hline $\mathrm{T}_{5}$ & 8.16 & 0.25 & 0.55 & 209.77 & 24.16 & 185.19 \\
\hline $\mathrm{T}_{6}$ & 8.31 & 0.18 & 0.53 & 207.86 & 22.19 & 181.41 \\
\hline $\mathrm{T}_{7}$ & 7.94 & 0.29 & 0.59 & 215.33 & 26.49 & 187.33 \\
\hline $\mathrm{CD}$ at 5\% & 0.156 & 0.05 & 0.054 & 1.42 & 0.573 & 0.624 \\
\hline
\end{tabular}


Table.6 Effect of different treatments on soil fertility of post-harvest soil

\begin{tabular}{|c|c|c|c|c|c|c|}
\hline Treatments & $\begin{array}{c}\text { Soil } \\
\text { biomass-C } \\
\left(\mu \mathrm{g} \mathrm{g}-{ }^{-1}\right)\end{array}$ & $\begin{array}{c}\text { Soil } \\
\text { biomass- } \mathbf{P} \\
\left(\mu \mathrm{g} \mathrm{g}-{ }^{-1}\right)\end{array}$ & $\begin{array}{c}\text { Soil biomass- } \\
\mathbf{N}\left(\mu \mathrm{g} \mathrm{g}{ }^{-}\right)\end{array}$ & \begin{tabular}{|c} 
Urease \\
activity $(\mu \mathrm{gg}$ g- \\
${ }^{1}$ soil hr- $\left.{ }^{1}\right)$
\end{tabular} & $\begin{array}{c}\text { Dehydrogenase } \\
\text { activity }(\mu \mathrm{g} \text { TPF } \\
\left.\mathrm{g}^{-1} \text { soil }^{-1}\right)\end{array}$ & \begin{tabular}{|c|} 
Alkaline \\
phosphatase activity \\
$\left(\begin{array}{c}\mu \mathrm{g} \text { p-nitrophenol g- } \\
\left.{ }^{1} \text { soil h}^{-1}\right)\end{array}\right.$
\end{tabular} \\
\hline$T_{1}$ & 136.61 & 10.40 & 28.10 & 194.77 & 133.57 & 41.23 \\
\hline $\mathrm{T}_{2}$ & 176.80 & 12.73 & 33.70 & 205.90 & 140.30 & 58.30 \\
\hline $\mathrm{T}_{3}$ & 187.72 & 14.00 & 38.43 & 214.13 & 147.71 & 77.83 \\
\hline $\mathrm{T}_{4}$ & 202.30 & 17.60 & 45.62 & 219.03 & 156.50 & 81.07 \\
\hline $\mathrm{T}_{5}$ & 230.40 & 20.10 & 52.40 & 229.08 & 164.57 & 104.51 \\
\hline $\mathrm{T}_{6}$ & 206.89 & 18.70 & 49.96 & 220.59 & 156.12 & 92.26 \\
\hline $\mathrm{T}_{7}$ & 234.80 & 23.60 & 54.26 & 231.45 & 177.39 & 109.27 \\
\hline $\mathrm{CD} @ 5 \%$ & 2.14 & 1.68 & 0.48 & 7.67 & 12.45 & 0.79 \\
\hline
\end{tabular}

The uptake of nutrients in rice crop was found maximum in treatment $\mathrm{T}_{7}\left(122.09 \mathrm{~kg} \mathrm{ha}^{-1}\right)$ and minimum in treatment $T_{1}\left(37.76 \mathrm{~kg} \mathrm{ha}^{-1}\right)$. The treatment $T_{1}$ was found to be significantly inferior to overall treatments. The increment in nitrogen uptake was probably due to improvement in soil condition due to application of FYM, make it easy to absorb nutrient by root. Good soil condition encouraged the proliferation of roots and improved synchrony between supply and plant demand, which in turn draw more nutrients from larger area and greater depth (Singh et al., 2013).

\section{Effect of different treatments on soil fertility of post-harvest soil}

The data related to soil $\mathrm{pH}$ under different treatments have been presented in Table 5. In general the $\mathrm{pH}$ of soil slightly decrease from initial value and (8.2) at all sites. The $\mathrm{pH}$ of soil of all two locations ranged between 8.0 and 8.19 , it was slightly decrease in treated plots but not changed in control plots. The lowest soil $\mathrm{pH}$ value was observed in treatment $T_{7}$ in all experimental sites. The highest soil $\mathrm{pH}$ value was recorded in treatment $T_{1}$ (control). The value of Organic carbon, available nitrogen, phosphorous and potassium was found increasing trend to targeted yield $\mathrm{T}_{7}$. This may be due to the fact that the application of higher amount of nitrogenous fertilizer (urea) for obtaining higher targeted yield. Hydrolysis of urea in soil reduces soil $\mathrm{pH}$ and application of farm yard manure increases microbial activity in soil, microbes releases organic acids during decomposition of organic matter, it was also decrease soil $\mathrm{P}^{\mathrm{H}}$. The overall treatment effect was found to be non-significant.

\section{Effect of different treatments on soil fertility of post-harvest soil}

In the Table 6, it was found that the minimum value of biomass carbon $\left(136.61 \mu \mathrm{g} \mathrm{g}^{-1}\right)$ was recorded in control $\mathrm{T}_{1}$ whereas in treatment $\mathrm{T}_{7}$, it was found higher value $\left(234.80 \mu \mathrm{g} \mathrm{g}^{-1}\right)$, as compare to other treatments, and same trends were found in case of soil biomass phosphorous and soil biomass nitrogen respectively. Soil microbial biomass is the living component of soil organic matter. As organic matters are the preferred energy source for the microorganisms, ecosystems with high organic substances tend to have higher microbial biomass contents as well as its activities. Moreover, reduction in microbial biomass and enzyme activities due to excessive cultivation practices have been reported earlier (Gupta and Germida, 1988). The minimum value of Urease enzyme activity was found (194.77 $\mu \mathrm{g} \mathrm{g}^{-1}$ soil h${ }^{-1}$ ) in $\mathrm{T}_{1}$ (control) however, in treatment $\mathrm{T}_{7}$ it was found higher value $\left(231.45 \mu \mathrm{g} \mathrm{g}^{-1}\right.$ soil $\left.\mathrm{h}^{-1}\right)$. For Alkaline 
phosphatase enzyme activity and Dehydrogenase enzyme activity, it was reported that the value shows increasing trends from control $\mathrm{T}_{1}$ to $\mathrm{T}_{7}$ treatments respectively. Such a pattern of impact may result in a relatively longterm effect on crop production. Poultry manure applied to a rice field at 120 or $180 \mathrm{~kg} \mathrm{~N} \mathrm{ha}^{-1}$ showed a residual effect on wheat, which followed rice, equivalent to $40 \mathrm{~kg} \mathrm{~N} \mathrm{ha}^{-1}$ (Singh et al., 1997). A study by Brzezinska et al., (1998) was reported that soil moisture content and temperature influence dehydrogenase activity indirectly by affecting the soil redox status. After flooding the soil, the amount of oxygen present in soil rapidly decrease so that a shift of the activity from aerobic to anaerobic microorganisms takes place.

It was concluded from the present investigation that the percent achievement of the targeted yield of all the two verification trials was within $\pm 5 \%$ variation proving the validity of the equations for prescribing integrated fertilizer doses for rice. The grain yield of rice from the two verification trials indicated that STCR-INM 40 and $50 \mathrm{q} \mathrm{ha}{ }^{-1}$ (target yield) was found significantly higher grain yield over all other treatments, whereas blanket fertilizer recommendation (farmer practice) recorded significantly lower yield. Among the treatments, STCR-INM recorded relatively higher benefit: cost ratio $3.87,3.94$ and 38.70 , 37.79 percent achievement than other treatments respectively. The results of this study confirmed that application of organic and inorganic fertilizers alter rice productivity and soil biological properties. The application of chemicals fertilizer and FYM were the most effective for increasing rice productivity and soil nutrient balance than sole chemical fertilizer or other amendments. Fertilization had a significantly beneficial impact on soil microbial properties. Farm yard manure and along with chemicals fertilizer application significantly improved soil microbial and enzymatic activity in soil. Based on data, it could be concluded that the combined application of chemical and organic (FYM) fertilizers@2t/ha could be rational strategy to sustain soil productivity as well as improving soil health status than the sole chemical fertilizer or organic (FYM) fertilizer application.

\section{Acknowledgement}

Ajay Babu is thankful to Dr. Y.V Singh for the technical help and also to Head of Department Soil Science and Agricultural Chemistry for providing necessary facilities and a token of thanks to the farmer A.M Maurya for technically mange the crop according to suitable requirement for experiment.

\section{References}

Barah, B.C. and Pandey, S 2005. Rainfed rice production system in Eastern India: An on farm diagnosis and policy alternatives. Indian Journal of Agriculture Economics, 60: 110-136.

Brzezinska, M, Stepniewska Z, Stepniewski 1998. Soil oxygen status and dehydrogenase activity, Soil Biol Biochem, 30:1783-1790.

Burns, R.G1986. Interaction of enzymes with soil mineral and organic colloids. In: Huang PM, Schnitzer M (eds) Interactions of soil minerals with natural organics and microbes. Soil Science Society of America, Madison, WI, pp 429-452.

Casida, L.E., Jr., D.A. Klein and T. Santoro 1964.Soil dehydrogenase activity. Soil Sci., 98: 371-376.

Dobermann, A., Witt, C., Abdulrachman, S., Gines, H. C., Nagarajan, R., Son, T.T. and Phung, C. V 2003. Soil fertility and indigenous nutrient supply in irrigated rice domains of Asia. Agronomy Journal, 95(4): 913-923.

Ge, G., Li, Z., Fan, F., Chu, G., Hou, Z. and Liang, Y 2010. Soil biological activity and their seasonal variations in response to long-term application of organic and inorganic fertilizers. Plant and Soil, 326(1-2): 31-44.

Gupta, V.V.S.R. and Germida, J.J. 
1988.Distribution of microbial biomass and its activity in different soil aggregate size classes as affected by cultivation. Soil Biology and Biochemistry 20: 777 786.

Jackson, M. L 1973. Soil Chemical Analysis: Prentice Hall of India Pvt. Ltd., New Delhi.

Masto,R. E., Chhonkar, P. K., Singh, D. and Patra, A. K. 2006. Changes in soil biological and biochemical characteristics in a long-term field trial on a sub-tropical inceptisol. Soil Biology and Biochemistry, 38(7): 1577-1582.

Mobley HL, Hausinger RP 1989.Microbial ureases: significance, regulation, and molecular characterization. Microbiol Rev 53:85-108.

Nannipieri, P., Ascher, J., Badalucco 2003. Microbial diversity and soil functions, European Journal of Soil Science, 54(4): 655-670.

Olsen, S. R., and Sommers, L.E., Phosphorus. In: Page A. L., Keeney D.R., Baker D.E., Miller R.H., Roscoe Ellis Jr. and Rhoades J.D 1954. Methods of soil analysis, Part 2.Chemical and Microbiological Properties, Agronomy Monograph No. 9 (Second edition), pp 403-429.

Polacco,J.C 1977.Plant Physiol, 54, 654-655.

Ramamoorthy, B., Narasimham, R. L. and Dinesh, R.S 1967. Fertilizer application for specific yield target of sonara-64 wheat. Indian Farming, 17 (5): 43-45.

Shah, R.A. and Kumar, S 2014. Direct and residual effect of integrated nutrient management and economics in hybrid rice wheat cropping system. AmericanEurasian J. Agric. and Environ. Sci., 14(5): 455-458.

Singh, A.K., Gautam, Singh, U.S., Singh J.,
Singh A.and Shrivastava, P 2015. Impact of nutrient management technologies in transplanted rice under irrigated domains of Central India. African Journal of Agricultural 10(5): 345-350.

Singh, B., Singh, Y., Maskina, M.S. and Meelu, O.P 1997. The value of poultry manure for wetland rice grown in rotation with wheat. Nutr Cycl Agroecosyst 47: 243250.

Singh, Y.V. and Singh, S.K 2014. Fertilizer prescription for targated yield of rice (Oryza sativa L. Var. Saryu-52) in an Inceptisol of Varanasi. Indian Journal Ecology, 42(2): 282-285.

Subbiah,B.V and Asija, G.L 1956. A rapid procedure for determination of available nitrogen in soils.current Science25,25960.

Tabatabai, M. A.1969. Soil Enzymes in method of soil analysis part- II Ed. Page, A.-1, Miller RH and Kannedy DR). American Society of Agronomy, Wisconsin, USA.

Tabatabai, M. A1994. Soil enzymes. Methods of Soil Analysis: Part 2 - Microbiological and Biochemical Properties, (methodsofsoilan2), 775-833.

Tejada, G., Romina, Lidia Giuffré and Rosario, Romero 2011. A soil quality index to evaluate the vermicompost amendments effects on soil properties. Journal of Environmental Protection 2.05:502.

Truog, E 1960. Fifty years of soil testing. Transactions of the $7^{\text {th }}$ International Congress of Soil Science, 3: 46-53.

Walkley, A. and Black, C.A 1934. An examination of degtazreff method for determining soil organic matter and a proved modification of chronic acid titration method. Soil Science, 37: 29-38.

\section{How to cite this article:}

Ajay Babu, Sudhanshu Verma, Sant Sharan Singh Yadav and Yad Vir Singh. 2017. Impact of Nutrient Management Technologies, Soil Biomass and Enzymatic Activities in Transplanted Rice (Oryza sativa L.) Under Irrigated Domains of Eastern Plain Zone in India. Int.J.Curr.Microbiol.App.Sci. 6(11): 4219-4227. doi: https://doi.org/10.20546/ijcmas.2017.611.494 